\title{
DISCURSO EM HOMENAGEM À PROFESSORA FÁTIMA VERDEAUX PARA A CERIMÔNIA DE OUTORGA DO TÍTULO DE EMÉRITA DA UnB
}

\author{
Marcello Ferreira \\ Universidade de Brasília - UnB
}

- Magnífica Reitora da Universidade de Brasília, Profa. Márcia Abrahão Moura

- Minha estimada colega e amiga, Professora Emérita da UnB, Dra. Fátima Verdeaux, a quem, em certas passagens de minha fala, tratarei apenas por Fátima.

- Ilustríssima Senhora Diretora em exercício do Instituto de Física da UnB, Profa. Vanessa Carvalho de Andrade, em nome de quem cumprimento a comissão que propôs a outorga de título de emérita à Profa. Fátima Verdeaux

- Prezados Professores, servidores técnico-administrativos alunos e ex-alunos

- Prezados familiares, colegas e convidados

\section{Bom dia a todos!}

O título de Professora Emérita constitui um dos maiores galardões da universidade. Sua outorga carrega a simbologia de que o agraciado se eterniza, se consagra como modelo de profissionalismo, de conduta ética e de dedicação à instituição. Mais do que isso, legitima e torna referência determinada maneira de ser e de atuar na pesquisa, no ensino e na extensão. Ser referência em uma universidade pública como a UnB, cabe destacar de partida, não é tarefa trivial.

Este momento resulta de iniciativa e demanda de uma comissão do Programa de PósGraduação em Ensino de Física do Instituto de Física da UnB, composta, além de mim, pelos professores Adriana Ibaldo, Ademir Santana, Joaquim Neto, Olavo Filho, Ronni Amorim e Vanessa Carvalho. A moção, de 15 de julho de 2018, foi aprovada por unanimidade, tanto no Conselho do Instituto, quanto no Conselho Universitário, que, em 10 de maio último, expediu resolução que sacramentou a honraria à 1391 emérita da UnB, desde 1974, quando a primeira outorga foi realizada.

Além de Fátima, somente outros dois físicos da UnB foram consagrados eméritos desta universidade, sendo ela a primeira entre as mulheres. Por este motivo, gostaria de cumprimentar a comunidade acadêmica da UnB em particular, os docentes, os técnicos e os 
alunos do nosso Instituto de Física que, com a anuência do Conselho Universitário, fizeram da concessão deste título um gesto de reconhecimento e justiça à qualidade acadêmica e científica e à dedicação profissional da nossa querida Professora Fátima Verdeaux.

No bojo desse reconhecimento, coube a mim, a um só tempo, a honra e a grande responsabilidade transmitir aqui em nome de um coletivo de familiares, amigos, colegas e admiradores uma mensagem cujo conteúdo minimamente se correlacione a tão distinta premiação; uma mensagem que tente aquilatar tão exitosa trajetória. Talvez o convite que me foi feito se justifique pelo emblema que carrego como seu ex-orientando de mestrado e, na atualidade, seu colega de ofício e de perspectivas. Seja como for, sinto-me orgulhoso e grato por fazer parte deste ato.

Mesmo reconhecendo que nesta intervenção não poderei ser capaz de esgotar os méritos de Fátima, gostaria de exaltar alguns aspectos que entendo ilustrarem seu percurso científico e profissional, em particular a sua formação e as contribuições dadas à UnB.

A trajetória acadêmica de Fátima inicia-se com a sua graduação em Física pela Pontifícia Universidade Católica de São Paulo, no ano de 1985. Em 1989, tornou-se mestre em ensino de física pela Universidade de São Paulo, discutindo a relação entre Ciência, Tecnologia e Sociedade, a partir de uma abordagem histórica da física moderna. Doutorou-se em 1995, também pela USP, tendo escrito a primeira Tese na área de ferrofluidos magnéticos no Brasil. Realizou, ainda, dois estágios pós-doutorais, na França, nos anos de 1997 e 2007.

Acumula, ao longo de sua carreira acadêmica, números que impressionam: são 38 artigos científicos publicados em periódicos nacionais e internacionais; um livro e dois capítulos de livro de sua autoria; 87 trabalhos apresentados em eventos científicos, além da orientação de 12 projetos de iniciação científica, 23 dissertações e uma tese. Atuou, com notório reconhecimento, nas áreas de Física e Ensino de Física, auxiliando e influenciando a formação de vários outros pesquisadores.

Somam-se a isso dezenas de atividades de participação e organização de eventos, composição de banca em concursos públicos para docentes, membro de comissão julgadora de teses e dissertações, organização de cursos e materiais instrucionais, consultorias em comissões científicas, editoria de periódicos especializados e coordenação de grupos de pesquisa, muitos deles com financiamento externo, captando efetivamente recursos vultosos e prestigiosos a esta universidade.

Foi na e para a universidade pública que nossa homenageada construiu sua carreira e ofereceu a sua contribuição às áreas de física e ensino de física. A relação de Fátima com a instituição universitária merece um capítulo particular, pois sempre se deu a partir do reconhecimento como instância de consciência crítica, expressão de uma sociedade democrática e pluricultural, lugar do respeito ao outro, da construção e da disseminação de saberes.

É esse espírito acadêmico que, cotidianamente, nas mais de duas décadas na UnB, serviu de inspiração para que a Fátima chegasse até aqui. Ao resgatar a trajetória de Fátima, lembro-me de um trecho literário que evoca a função de professor. No livro Conversas com quem gosta de Ensinar, Rubem Alves registra que

[...] a filha de um coronel diz à sua mãe que pretendia casar-se com um professor. Ao que a mãe retruca, numa clássica lição de realismo político: 
E o que é um professor, na ordem das coisas?

Que tem o ensino a ver com o poder?

Como podem as palavras se comparar com as armas?

Por acaso a linguagem já destruiu e já construiu mundos?

Essas perguntas, feitas de outro modo, não querem outra coisa senão refletir acerca do papel do professor. E então, o que é o professor na ordem das coisas?

Exaltando sua função docente, a carreira universitária da Professora Fátima Verdeaux esteve sempre vinculada à reflexão a respeito do que seria o professor na ordem das coisas. Isto é, quem somos nós, professores, e como influenciamos a concretude da vida?

Em aulas que tive a honra de ministrar juntamente com a Professora Fátima Verdeaux, no Programa de Pós-Graduação em Ensino de Física, dentre muitos outros temas para discutir teorias e metodologias no ensino de física, recorremos por vezes ao pensamento Marxista para ler e compreender o mundo. Fizemos isso na perspectiva de vários autores, de várias epistemologias. Mas Marx nos forneceu uma forma radical, e sempre muito presente, a capacidade de captar e representar o movimento ideal do objeto real, para, com isso, criticar a nossa sociedade e suas vicissitudes, bem como os seus problemas estruturais.

Fizemos isso da forma como Fátima sempre prezou o ensino de física, a partir de rigor científico e vigilância teórica. Foi por essa lente que discutimos que é dever de todos nós, trabalhadores, nos constituirmos em uma classe para si, que busca reconhecer os elementos que lhe constituem e as relações socioeconômicas que ditam a ordem das coisas.

O nosso papel, como professores, tem sido o de democratizar as múltiplas formas de pensar e o de fomentar as microrevoluções, cotidianas, em sua maior parte silenciosas, que se constituem do desejo de todos pela reorganização das formas de pensar os sistemas produtivos e a educação que lhes serve.

Por outro lado, discutimos também, pelo viés do filósofo Michel Foucault, que não estamos em outro domínio senão o de discursos. Foucault não se deteve a pensar as relações sociais na estrutura econômica. Ao discutir que transitamos em espaços sociais diferentes, cada qual com suas regras, suas ideias, suas lógicas, ele tensionou a ideia de que nos cumpre compreender o nosso papel, como agentes políticos. Mais do que isso, que cabe tomar a nós a compreensão de que somos parte desses sistemas sociais bem definidos e que compreendê-los, sabe-los é, ao mesmo tempo, fonte e consequência de relações de poder.

$\mathrm{Na}$ matriz de que deriva o pensamento foucaultiano, Nietzsche, em diversos textos, reflete que, por trás de todo o saber, de todo o conhecimento, está em jogo uma luta de poderes. O poder político não está ausente do saber, ele é tramado com o saber. E Foucault nos coloca que é papel da universidade reconstituir as relações de poder. Fátima tomou a si esse papel: ela operou, em sua trajetória acadêmica, pela reconfiguração das relações de saber-poder que determinam a ordem das coisas. Foi, por vezes, determinada e determinante na ordem das coisas.

Qual seria, então, retomando a questão de Rubem Alves, o nosso papel nessa ordem das coisas? Cada um de nós deverá individualmente encontrá-lo. A universidade, em seu papel plural, tem a virtude de nos confrontar, diariamente, com visões de mundo como essas de que aqui tratamos. Essa clarividência de que todas as formas de pensamento, inclusive a 
ciência, não são coisa outra senão a peça de uma engrenagem é o que traz Fátima até essa ocasião, é o que move o legado de Fátima na universidade.

O que a trouxe para essa consagração foi também uma visão pertinente da política pública, da universidade e de sua função social, seus meios e seus processos. Dito isso, volto à pergunta: o que foi a professora Fátima Verdeaux na ordem das coisas desta universidade e do ensino de física no Distrito Federal? Como ela atuou em frentes que se conectam à rede de saberes e poderes da nossa sociedade? Que papel ela teve e tem no desafio de subverter essa mesma ordem das coisas?

Fátima foi dedicada e proeminente professora, atuando com destaque na licenciatura em Física da UnB, desde o seu ingresso como docente da UnB, em 1997, e, mais recentemente, no ano de 2012, na criação e coordenação do Mestrado Nacional Profissional em Ensino de Física o MNPEF. Esse empreendimento, em particular, merece destaque, pois foi por meio dele que, nesses últimos anos de atuação antes de se aposentar, ela consubstanciou as décadas de pesquisa e atuação na formação de professores de Física. O MNPEF da UnB tem o DNA acadêmico da Professora Fátima Verdeaux, associando a melhor física, teorias e metodologias de ensino contemporâneas e uma clara ação social para a democratização e qualificação do ensino, com pragmatismo e consistência teórica.

A Professora Maria de Fátima da Silva Verdeaux, de fato, alcançou destaque em sua vida como pesquisadora, professora e, sobretudo, intelectual. Ela protagoniza este momento, de maneira legítima e muito merecida, sendo impossível distingui-la desta instituição universitária que nesta data a reconhece e exalta. A Universidade de Brasília, o Instituto de Física, suas licenciaturas presencial e EaD e suas pós-graduações em Física e em Ensino de Física só existem porque, ao longo de décadas, se conjugaram políticas públicas educacionais voltadas à descentralização e à expansão da oferta de ensino superior no País.

Esse movimento não pode ser analisado, senão no conjunto de outros esforços do Brasil para superar o déficit de professores na Educação Básica, estimado atualmente em 170 mil. Tal déficit explica, ao menos em parte, os pífios resultados educacionais do Brasil. Lamentavelmente, não é novidade para nenhum aqui presente que a nossa população é pouco e mal escolarizada. Não é só a nossa ciência e a nossa indústria que padecem desse mal. É a nossa sociedade também, que em face dessa mesma má formação, se vê agredida por toda sorte de problemas políticos, culturais, educacionais, ambientais, tecnológicos e éticos. Fátima soube ler com atenção e atuar de maneira efetiva diante desse cenário, colaborando de forma objetiva, consistente e qualificada para a formação de professores de ciências no Distrito Federal.

Ainda na tentativa de resgatar as sobejas razões para a outorga de tão significativo título, não posso me furtar de registrar características pessoais de Fátima que, de certo modo, potencializaram a sua constituição como professora, de forma precisa e transformadora.

Se eu pudesse definir Fátima com uma só expressão, diria que ela é uma mulher de fortes convicções. Os que não contemporizarem tal característica ao papel difícil e não óbvio de mulher na física, militante política do campo progressista, cientista, professora e acadêmica de importantes realizações poderão cair na tentação primeira na real armadilha de reduzi-la à expressão mais cutânea dessa característica que lhe assiste, acabando por qualificá-la, em grosseira aproximação, como durona.

De fato, durona ela é. Esse adjetivo é aderente a uma de suas marcas indeléveis: o 
posicionamento sempre firme diante de suas convicções. Foi assim que ela se habituou a respeitar o contraditório e se fez respeitada em suas singularidades. Isso certamente não foi nada natural em relação ao lugar-de-fala que ocupa.

Nesses tempos de modernidade líquida, em que quase tudo se esvai, essa característica nos parece ser muito mais que uma mera marca de personalidade. Ela é, pois, o repertório de uma luta política sempre em vigília, de um gesto permanente em benefício de práticas de liberdade. Em tempos de frivolidade e inconsistência, Fátima é retrô: se relaciona intensamente com aqueles em quem confia e se mantém combativa em face daquilo em que acredita.

Falar de Fátima é também reconhecer a sua formação científica sólida, sua visão estratégica diante dos desafios da área de ensino de ciências, sua capacidade de agregar e mobilizar o melhor do coletivo para projetos eminentemente coletivos. Mesmo durona, Fátima é também meio-termo, é escuta, é solidariedade. Fátima tem amor à universidade e ao melhor conhecimento. Fátima respeita a ciência e suas formas de expressão. Fátima tem também sua dualidade: ela é bronca e candura, na mesma mulher, sob os mesmos princípios. Fátima ensina, aprende, luta, diverge, acerta e erra. Fátima, enfim, é nossa emérita. Parabéns, Fátima. E assim você se eterniza!

Brasília-DF, 6 de dezembro de 2019.

Prof. Marcello Ferreira

Universidade de Brasília 